\title{
Treatment of hepatitis C virus infection
}

\author{
Kilian Weigand, Wolfgang Stremmel, Jens Encke
}

Kilian Weigand, Wolfgang Stremmel, Jens Encke, University of Heidelberg, Department of Gastroenterology and Hepatology, Im Neuenheimer Feld 410, Heidelberg 69120, Germany Correspondence to: Professor J Encke, University of Heidelberg, Department of Gastroenterology, Im Neuenheimer Feld 410, Heidelberg D-69120, Germany. jens_encke@med.uni-heidelberg.de Telephone: +49-6221-5638825 Fax: +49-6221-566858

Received: 2007-01-11 Accepted: 2007-03-14

\begin{abstract}
Acute and chronic hepatitis C virus (HCV) infection remains a serious health problem worldwide, however, there has been advancement in the treatment of $\mathrm{HCV}$ infection due to standard treatment using pegylated interferon and ribavirin. The literature indicates that therapy for $\mathrm{HCV}$ is becoming more individualized. In addition to considering genotype and viral RNA levels before treatment, achievement of an early virologic response (EVR) and a rapid virologic response (RVR) is now possible during therapy. Moreover, problem patients, such as non-responders, relapsers, HIV or HBV coinfected patients, patients with liver cirrhosis, and preor post-liver transplantation patients are an increasing fraction of the patients requiring treatment. This article reviews the literature regarding standard treatments and problem patients with acute and chronic HCV infection. It also includes discussion on contraindications and side effects of treatment with interferon and ribavirin, as well as new drug development.
\end{abstract}

(c) 2007 The WJG Press. All rights reserved.

Key words: Hepatitis C virus; Acute and chronic HCV infection; Treatment; Pegylated interferon; Ribavirin; Sustained virologic response; Non-responders; Relapsers

Weigand K, Stremmel W, Encke J. Treatment of hepatitis C virus infection. World J Gastroenterol 2007; 13(13): 1897-1905

http://www.wjgnet.com/1007-9327/13/1897.asp

\section{INTRODUCTION}

Infection with hepatitis $\mathrm{C}$ virus (HCV) remains a severe life-threatening medical and public health problem worldwide. Every year there are an estimated 3 to 4 million new cases of infection due to transfusion contamination, contaminated injection needles, and parenteral exposure ${ }^{[1-5]}$.
There is a lower rate of infection for sexual transmission ${ }^{[6]}$. About $55 \%-85 \%$ of individuals with acute HCV infection become chronically infected and are at risk for developing hepatocellular injury, liver cirrhosis, hepatocellular carcinoma or liver failure ${ }^{[7-9]}$.

In total, More than 170 million individuals $(>2 \%$ of the world's population) are infected with $\mathrm{HCV}^{[10]}$. While prevention of primary infection is possible, vertical transmission of $\mathrm{HCV}$ remains a significant problem especially in developing countries.

The transition from acute to chronic infection is only partly understood. However, early treatment with pegylated interferon (PEG-IFN) alpha to prevent chronic infection is effective in up to $95 \%$ of patients with acute hepatitis ${ }^{[11-13]}$. Determining the optimal treatment for chronically infected individuals is a remaining question. To date, standard treatment for chronically infected patients is the combination of PEG-IFN alpha with ribavirin ${ }^{[14]}$. Recent studies have demonstrated that a relatively high number of patients acquire sustained virologic response (SVR), defined as non-detectable serum virus RNA levels by qualitative PCR 6 mo after end of treatment ${ }^{[15,16]}$, and this is the primary goal of therapy. However, a large number of patients remain viraemic and chronically infected. In addition, many patients suffer from severe side effects while receiving this combination therapy ${ }^{[14-17]}$. These are the reasons for attempts to find medications with higher SVRs, better tolerability and shorter treatment regimens ${ }^{[18-21]}$. Moreover, alternative therapeutic regimens, such as an effective therapeutic or prophylactic vaccine for HCV infection, are being sought after and developed ${ }^{[22-26]}$.

\section{TREATMENT OF ACUTE HEPATITIS C}

Diagnosis of acute HCV infection is a rare event since acutely infected individuals are mostly asymptomatic ${ }^{[27,28]}$. Also, social problems within high risk groups (especially injection drug users) keep these individuals from seeing physicians.

An optimal treatment for acute HCV infections has not been established. There are several studies showing excellent responses using IFN $\alpha^{[11]}$. The best results, with a SVR in over $95 \%$ of the patients, were achieved by using 5 million international units (MIU) of IFN daily for $4 \mathrm{wk}$, followed by 5 MIU three times weekly for another $20 \mathrm{wk}$. This treatment was well tolerated in most cases. Another recent study achieved a SVR in $87 \%$ of patients, using 6 MIU of IFN injected intramuscularly daily for $4 \mathrm{wk}^{[29]}$. In acute HCV, genotype and RNA serum levels seem to have no influence on treatment outcomes ${ }^{[11,30]}$. While undergoing treatment, patients need to be monitored at 
least every four weeks for transaminases, $\mathrm{HCV}$ antibodies and serum RNA levels.

Since spontaneous viral clearance is documented in up to $50 \%$ of acutely infected individuals ${ }^{[13,30-32]}$, some authors believe treatment should be initiated after three to four months of observation. The data to date show a worse outcome following this policy ${ }^{[1,13]}$, but patients avoid the potential severe side effects of IFN therapy ${ }^{[33]}$. Also, this scheme gives an opportunity for patients with contraindications to IFN therapy; i.e. pregnancy, acute alcohol or i.v. drug abuse, and psychiatric diseases such as severe depression, to resolve these problems before starting therapy ${ }^{[14,17,34]}$. Nevertheless, delaying therapy for acute HCV infection beyond three months after onset of the disease cannot be recommended since one study showed this resulted in a dramatic drop of SVR rates (from $87 \%$ to $53 \%)^{[29]}$. Even if IFN monotherapy is sufficient for the therapy of acute HCV infection ${ }^{[35]}$, preliminary data suggest PEG-IFN to be as effective as the IFN regime used in the reported German trial ${ }^{[35]}$. Recently, Wiegand et a ${ }^{{ }^{12]}}$ published a trial using PEG-IFN alpha-2b $1.5 \mu \mathrm{g}$ per $\mathrm{kg}$ body weight with patients that had acute $\mathrm{HCV}$ infection. In patients adherent to therapy, a SVR of $94 \%$ after therapy and $89 \%$ after a follow up of 24 wk was achieved. In nonadherent patients (less than $80 \%$ of PEG-IFN application in $80 \%$ of scheduled treatment duration), the rates dropped to $82 \%$ and $71 \%$, respectively. Furthermore, Kamal et a ${ }^{[36]}$ presented a study demonstrating a combination therapy of PEG-IFN and ribavirin to be more effective than PEG-IFN monotherapy (increase of SVR from $80 \%$ with monotherapy to $85 \%$ with combination therapy). In addition, it was shown that the time point to start treatment after onset of disease is very important. A recent trial demonstrated that overall SVR dropped from 95\% to $92 \%$ and then to $76 \%$ when treatment was started 8,12 or 20 wk after onset of disease ${ }^{[37]}$, respectively. Considering these data, we suggest treating acute HCV infection for $24 \mathrm{wk}$, starting immediately or at three months after onset of the disease, using a combination of PEG-INF and ribavirin in a dosage recommended for treatment of chronic HCV infection (see below).

\section{TREATMENT OF CHRONIC HEPATITIS C}

The primary treatment goal for chronic HCV infection is, as mentioned previously, sustained virologic response $(\mathrm{SVR})^{[38,39]}$. With the recommended treatment, SVR can be achieved in about $55 \%$ of patients who are chronically infected with genotype 1 of $\mathrm{HCV}$, while with genotype 2 and 3 the efficacy is $80 \%$ or greater ${ }^{[15,16,40]}$. The standard therapy is PEG-IFN alpha-2a or PEG-IFN alpha-2b subcutaneously in combination with twice daily oral doses of ribavirin ${ }^{[15,16,41]}$. The combination has proven to be more efficient than monotherapy alone, even though the antiviral mechanism of ribavirin is not fully understood ${ }^{[42]}$. Ribavirin monotherapy has no therapeutic effect in $\mathrm{HCV}$ infected patients ${ }^{[43,44]}$.

There are two widely accepted regimens that can be followed, with both showing comparable SVR rates. Published in 2001 by Manns et al ${ }^{[15]}$, PEG-IFN alpha$2 \mathrm{~b}$ in a dose of $1.5 \mu \mathrm{g}$ per $\mathrm{kg}$ body weight once a week subcutaneously plus oral ribavirin $800 \mathrm{mg}$ daily led to a virus clearance of $54 \%$. Higher ribavirin doses resulted in a lower efficacy. While genotype 1 must be treated for 48 wk to achieve the best results, treatment longer than 24 wk for genotype 2 and 3 did not raise SVR rates beyond $82 \%$. A trial by Fried et a ${ }^{[16]}$ using PEG-IFN alpha-2a demonstrated comparable results. Using PEG-IFN alpha$2 \mathrm{a}$ in a dose of $180 \mu \mathrm{g}$ once a week subcutaneously plus 1000-1200 mg (depending on body weight, cut-off $75 \mathrm{~kg}$ ) of oral ribavirin daily resulted in $56 \%$ of SVR in genotype 1 carriers, and $80 \%$ in genotype 2 and 3 carriers. Patients with genotype 1 were treated for $48 \mathrm{wk}$. In patients infected with genotype 2 and 3, a treatment period of 24 wk seemed to be sufficient. Recently, two studies have shown that treatment can be abbreviated in patients with low baseline levels of HCV-RNA ( $600000 \mathrm{IU} / \mathrm{mL})$ who become HCV-RNA negative. Treatment of genotype 2 and 3 for only 12 or 16 wk may be sufficient for a special population ${ }^{[45,46]}$. Therefore, therapy for $\mathrm{HCV}$ infection is becoming an individualized therapy.

In summary, for patients who are chronically infected with HCV, the recommendation is to use PEG-IFN alpha2b $1.5 \mu \mathrm{g} / \mathrm{kg}$ per week or PEG-IFN alpha-2a $180 \mu \mathrm{g} / \mathrm{wk}$ plus ribavirin 1000-1200 mg/d (body weight dependent) for 48 wk for patients with genotype 1 or 24 wk for patients with genotype 2 or 3 . For genotypes 4, 5 and 6, the data are not sufficient for the development of a guideline, but it has been suggested to treat patients with these genotypes in a similar way as for patients with genotype $1^{[47,48]}$. Recently, Hadziyannis et al ${ }^{[40]}$ presented a study on 36 genotype 4 carriers. While patients in the short-term group (24 wk) had a SVR of $63 \%-67 \%$, treatment for $48 \mathrm{wk}$ resulted in a SVR of 82.

Induction therapy does not result in higher SVR rates, therefore a recommendation regarding induction therapy cannot be given ${ }^{[49,50]}$, but there are ongoing individual trials. While it is recommended to treat patients with relapse of $\mathrm{HCV}$ or non-responders after IFN alpha monotherapy with the described combination of PEG-IFN and ribavirin ${ }^{[51-54]}$, the treatment indication for non-responders or patients with relapse after treatment with PEG-IFN alpha and ribavirin is controversial. Recent studies do not offer a general recommendation. Controlled trials to answer this question are ongoing.

During therapy, monthly monitoring of side effects, blood count, transaminases, creatinine, urea and glucose should be made. For the first 2 mo of therapy, blood counts should be made every $2 \mathrm{wk}$. Thyroid function should be considered in 12 wk intervals by measuring thyroid stimulating hormone (TSH). To monitor treatment efficacy, HCV-RNA should be determined quantitatively before and $12 \mathrm{wk}$ after the start of therapy. If the RNA level drops less than 2 logs-known as early virologic response (EVR)-or remains detectable at wk 24 , a successful treatment is extremely unlikely and therapy should be stopped ${ }^{[15,16,55-58]}$. The same is true if after $24 \mathrm{wk}$ HCV-RNA is still measurable ${ }^{[59]}$.

As mentioned above, successful treatment is defined as SVR and undetectable HCV-RNA 6 mo after the end of therapy. A recently described predictive factor is the rapid virologic response (RVR), defined as undetectable 
HCV RNA levels at wk 4 after the start of treatment. For patients who have genotype 1 with a low baseline viral load ( $<600000 \mathrm{IU} / \mathrm{mL}$ ) and who have achieved RVR under therapy with continuous undetectable HCV-RNA afterwards, a treatment course of $24 \mathrm{wk}$ may be required to match comparable results to the standard treatment of $48 \mathrm{wk}^{[60]}$. For patients with genotype 2 or 3 and a RVR followed by undetectable RNA levels, therapy for 16 or even $12 \mathrm{wk}$ may be sufficient ${ }^{[46]}$. However, reducing treatment duration in these patient populations remains controversial $^{[61]}$. Therapy to increase SVR and reduce sideeffects for chronic HCV infected patients is becoming more often designed for the individual, with genotype, EVR, RVR and the HCV-RNA level before start of treatment as predictors for achieving a SVR.

\section{TREATMENT OF HEPATITIS C INFECTION IN CHILDREN}

Children suffering from chronic HCV infection generally show no symptoms. While biochemistry and histology are comparable to adults with $\mathrm{HCV}$, the progression of hepatitis $C$ seems to be slower compared to adults ${ }^{[62-64]}$. It has been shown that, in general, children tolerate IFN therapy relatively well. Side effects are usually mild or moderate. One study of 41 children receiving standard combination therapy showed an overall SVR of $61 \%$ one year after treatment ${ }^{[65]}$. Altogether response rates in children to INF monotherapy and combination therapy with INF and ribavirin seem to be equivalent to adults $^{[14,64,66,67]}$, PEG-IFN is not yet approved for use in children. Therefore, the present regime is $15 \mathrm{mg}$ ribavirin per $\mathrm{kg}$ body weight per day plus $3 \mathrm{MIU} / \mathrm{m}^{2}$ body surface interferon alpha- $2 \mathrm{~b}$ three times per week ${ }^{[68]}$. This treatment appears to be reasonably safe and effective in children with hepatitis C. Prospective controlled trials evaluating combination therapy with PEG-INF are being developed.

\section{SIDE-EFFECTS AND CONTRAINDICATIONS FOR TREATMENT OF HEPATITIS C INFECTION}

Should everybody with chronic HCV infection be treated? Patients with signs of hepatitis, such as elevated transaminases (serum alanine aminotransferase level, ALT), and beginning fibrosis in liver biopsy are thought to be the most appropriate group to undergo therapy ${ }^{[14,69]}$. Nevertheless, patients with normal transaminases have the same outcome as individuals with elevated $\operatorname{ALT}^{[70]}$.

People without the necessary motivation and compliance to therapy should be considered as untreated. Costs of treatment and severe side-effects must be weighed against the low efficacy of therapy in this $\operatorname{group}^{[14,34,71,72]}$.

There are some absolute and relative medical contraindications for treatment with IFN, PEG-IFN and/or ribavirin. Since ribavirin is teratogenic, in both males and females, anticonception is recommended during therapy and at least 6 mo after end of therapy ${ }^{[73]}$.
Also breast feeding should be avoided. People with cardiac problems rarely develop reversible arrhythmia ${ }^{[7]}$ or cardiomyopathy ${ }^{[75]}$ under interferon therapy. But for patients with significant cardiac disease, death from cardiac failure is more likely than from chronic hepatitis C. Therefore, within this patient group anti-viral therapy can be dispensed.

Further contraindications for treatment with interferon and/or ribavirin are hepatic decompensation and renal failure. Interferon and ribavirin can enhance liver failure ${ }^{[76}$ and, as mentioned above, close monitoring is required. Some hepatic comorbidities, additional to chronic HCV infection, are discussed later. Ribavirin undergoes renal elimination. Therefore, renal impairment leads to elevated serum levels of ribavirin, enhancing side-effects such as hemolysis. The same is true for INF, while PEG-IFN, due to its molecular size, is better tolerated in patients with end stage renal disease. PEG-IFN alpha-2a does not result in elevated serum levels even with creatinine clearance $<30 \mathrm{~mL} / \mathrm{min}$. Since kidney diseases often do not limit life expectancy, antiviral therapy must be considered in patients with both chronic HCV and end-stage renal disorder ${ }^{[77,78]}$. Available data suggests higher SVR rates in patients with renal disease, using IFN monotherapy, compared to patients with normal renal function ${ }^{[79,80]}$. Few studies have dealt with very low dose ribavirin application in these patients ${ }^{[81,82]}$, alone or in combination with PEGINF. PEG-INF $\alpha-2$ a should be reduced from $180 \mu \mathrm{g}$ to $135 \mu \mathrm{g}$, while the recommendation for PEG-INF $\alpha-2 \mathrm{~b}$ is dose reduction by $50 \%{ }^{[83]}$.

The immune system is heavily influenced by both ribavirin and interferon and this is the probable mechanism of their antiviral activity. But in $\mathrm{HCV}$ patients with comorbid autoimmune disease, both drugs could worsen the disease. Therefore, application of antiviral therapy must be considered dangerous as long as the autoimmune disease is not controlled.

The most common side effects of treatment with PEG-IFN are fatigue, muscle aches and psychological disorders such as depression, irritability, anxiety and sleep disturbance. Interferon further induces pancytopenia through its bone marrow depressing activity ${ }^{[15,16,84]}$. The most common adverse effect of ribavirin is haemolysis and anaemia. Therefore, patients treated with the combination therapy suffer from anaemia, with the lowest haemoglobin $4 \mathrm{wk}$ after initiation of treatment ${ }^{[84]}$. Patients with ischaemic problems should be monitored closely and, if necessary, should have blood components transfused. The application of growth factors, such as erythropoetin, G-CSF or GM-CSF, cannot generally be recommended considering the cost-benefit-ratio, but growth factors may be useful in some patient populations. Significantly higher risk for bacterial infection has not been demonstrated during treatment with ribavirin and/or PEG-IFN ${ }^{[15,16,85,86]}$. The most common autoimmune reaction to therapy is the development of autoimmune thyroiditis ${ }^{[15,16,84,85,87]}$. Flu symptoms caused by interferon can be treated with paracetamol or similar drugs ${ }^{[84]}$, and thyroid disorders by hormone application. More severe side effects are mood changes and depression ${ }^{[15,16,84,88]}$. The later is especially true in people already suffering from instable psychiatric 
disorders prior to therapy. Mild symptoms can be covered by selective serotonin reuptake inhibitors (SSRI) ${ }^{[89]}$, while development of severe depression or suicidal tendencies are clear indications to discontinue therapy.

Rare side-effects are hearing impairment, hair thinning and loss, insomnia, visual disorders, interstitial pneumonia, pancreatitis, colitis and exacerbation of inflammatory diseases ${ }^{[83,84]}$. Every patient should be informed sufficiently about potential adverse events before therapy is started.

\section{TREATMENT OF HEPATITIS C IN PATIENTS WITH LIVER CIRRHOSIS}

Mortality from hepatitis $\mathrm{C}$ is mainly due to manifest cirrhosis. Liver biopsy studies indicate that hepatic fibrosis may regress under therapy with PEG-IFN and ribavirin ${ }^{[90,91]}$. The recommendation today is to treat patients with compensated cirrhosis with the standard combination therapy ${ }^{[92,93]}$. While patients with Child-Pugh A and $\mathrm{B}$ cirrhosis respond and tolerate this therapy relatively well ${ }^{[15,16,40,87,94]}$, it is unclear whether a drug reduction in Child C cirrhosis should be recommended ${ }^{[95-97]}$. In general, antiviral therapy in decompensated liver cirrhosis is not recommended $^{[98]}$.

There is data indicating that reduction of body weight in obese patients is associated with reduction in hepatic fat $^{[99,100]}$ and in some cases of fibrosis ${ }^{[101]}$, resulting in a better response to antiviral treatment.

A study carried out on a Japanese population demonstrated the prevention of hepatocellular carcinoma (HCC) in individuals receiving antiviral therapy ${ }^{[102]}$. The same effect may be found in Caucasians ${ }^{[103,104]}$. Successful antiviral therapy also reduces the rate of hepatic decompensation.

Overall, even if liver transplantation in end-stage disease is not prevented by antiviral therapy, the data suggest that recurrence of disease after transplantation is significantly lowered if treated previously ${ }^{[76]}$.

\section{TREATMENT OF HEPATITIS C IN PATIENTS AFTER LIVER TRANSPLANTATION}

Chronic HCV infection with end-stage liver disease or hepatocellular carcinoma due to $\mathrm{HCV}$ is currently the most common indication for liver transplantation ${ }^{[105,106]}$. All transplanted patients become reinfected with $\mathrm{HCV}^{[107-111]}$ and, combined with immune suppressive therapy to avoid rejection of the organ, some patients develop rapid progressive hepatitis ${ }^{[109,112-115]}$. In addition, acute rejection seems more frequent in patients with liver transplantation for hepatitis $C^{[116,117]}$.

Before transplantation, the patient should be treated for HCV infection, if possible (see above) ${ }^{[96,97,118]}$. Unfortunately, most patients in need of transplantation have decompensated disease, limiting effective antiviral therapy before transplantation ${ }^{[76]}$. Even when IFN combined with ribavirin was previously used ${ }^{[119-121]}$, after transplantation the standard treatment should be PEGIFN and ribavirin ${ }^{[122-128]}$. Nevertheless, SVR rates posttransplantation were significantly worse compared to antiviral treatment in the non-transplantation setting. Overall, SVR rates post-transplantation are only about $20 \%{ }^{[119,123,127,129-131]}$. Furthermore, in a high percentage of patients, interferon and ribavirin are poorly tolerated after liver transplantation and therapy must be considered carefully $^{[83,131]}$.

\section{TREATMENT OF HEPATITIS C IN PATIENTS CO-INFECTED WITH HIV}

There is a high rate of patients co-infected with HCV and HIV due to the same transmission route in highrisk populations. An estimated $25 \%-30 \%$ of patients with HIV are co-infected with HCV in Europe and the United States ${ }^{[132]}$. In these patients, HCV progression to endstage liver disease is almost doubled ${ }^{[133,134]}$. Therefore, it is favourable to treat these patients as early as possible, if they have no other contraindications.

Since therapy for HCV does not significantly increase HIV RNA levels, it is recommended to use standard treatment with PEG-IFN and ribavirin. SVR rates in co-infected patients are slightly lower than in the mono-infected population ${ }^{[135,136]}$. For genotype 1 (and 4), SVR ranges from $14 \%$ to $29 \%$, while for genotype 2 and 3 it ranges from $44 \%$ to $73 \%{ }^{[137-139]}$. Patients on antiretroviral therapy are more likely to develop the side-effects of ribavirin ${ }^{[139-141]}$. These patients must be monitored closely and, in the case of severe side effects, ribavirin should be reduced or discontinued.

If HIV infection itself is not stable (CD4 count $<200$ cells $/ \mathrm{mm}$ ), highly active antiretroviral therapy (HAART) should be initiated first and secondarily, after stabilisation, treatment for HCV should be started $\mathrm{d}^{[142-144]}$.

\section{NEW THERAPEUTIC IDEAS FOR PATIENTS INFECTED WITH HEPATITIS C}

Since the number of non-responders or patients with relapse is increasing, many new drugs are being tested briefly. Meta-analysis of several controlled trials for amantadin, for example, showed a significantly better SVR with amantadin and IFN alpha compared to IFN alpha monotherapy ${ }^{[19,20,145]}$. Further, a German study showed an increase of SVR using a triple therapy of INF alpha plus ribavirin plus amantadin compared to INF alpha plus ribavirin plus placebo ${ }^{[18]}$. Still missing are trials with PEGINF, ribavirin and amantadin, as well as studies looking at long-term outcomes.

Further, alternative interferon types and ribavirin analogues, for example viramidine, which is a ribavirin prodrug cleaved to ribavirin in the liver, were tested to reduce side effects and were found to vary in succes ${ }^{[146-148]}$. Most promising are specific inhibitors, such as specific HCV protease and HCV polymerase inhibitors, which were tested in experimental settings or phase 1-2 studies currently $^{[21,26]}$. In phase 1 and 2 trials, several HCV specific protease inhibitors, such as BILN 2061, VX 950, SCH 503034, demonstrated a reduction of HCV RNA levels from 2 to $4.4 \log _{10}$ from baseline $e^{[149-153]}$. Due to cardiac toxicity, further development of BILN 2061 has been 
stopped. VX 950, which is another protease inhibitor, significantly lowers HCV-RNA levels more than $4 \log _{10}$ units within the first $14 \mathrm{~d}^{[154]}$. Unfortunately, in the followup, the concentration increased again, probably due to mutational resistance. Nevertheless, since RVR is a strong positive predictive factor, a combination of standard therapy together with VX 950 could increase SVR rates. Similar results are true for SCH 503034 with a HCVRNA drop of 2 to $3 \log _{10}$ units. Also, specific polymerase inhibitors and nucleosid analogues have been tested for reduction of HCV RNA levels ${ }^{[155,156]}$. They result in a reduction of HCV-RNA concentrations, but they seem to be less effective in their antiviral activity than protease inhibitors ${ }^{[157]}$. Studies combining polymerase inhibitors with standard therapy are ongoing and it is most likely that polymerase and protease inhibitors will be combined with PEG-IFN in the future.

Additional concepts are the use of toll-like receptor agonists and RNA-based therapy ${ }^{[26]}$, as well as drugs like thymosin- $\alpha$, inosinmonophaphatedehydrogenase inhibitors, anti oxidants, glucosidase inhibitors, cytokines, inhibitors of the internal ribosomal entry site (IRES) and fusion proteins. Silymarin, which in some cases resulted in a drop of the transaminases, does not produce an effect on HCV-RNA concentration and liver histology in the trials presented to date. Most eagerly, many approaches involve a search to find a vaccine to prevent HCV infection ${ }^{[24,25,158]}$.

\section{ACKNOWLEDGMENTS}

We gratefully thank Kerstin Stein, MD and Christoph Eisenbach, MD of our department for proof reading and critical comments on the manuscript.

\section{REFERENCES}

1 Alter MJ. Hepatitis C virus infection in the United States. J Hepatol 1999; 31 Suppl 1: 88-91

2 Murphy EL, Bryzman SM, Glynn SA, Ameti DI, Thomson RA, Williams AE, Nass CC, Ownby HE, Schreiber GB, Kong F, Neal KR, Nemo GJ. Risk factors for hepatitis C virus infection in United States blood donors. NHLBI Retrovirus Epidemiology Donor Study (REDS) Hepatology 2000; 31: 756-762

3 Conry-Cantilena C, VanRaden M, Gibble J, Melpolder J, Shakil AO, Viladomiu L, Cheung L, DiBisceglie A, Hoofnagle J, Shih JW. Routes of infection, viremia, and liver disease in blood donors found to have hepatitis $\mathrm{C}$ virus infection. $N$ Engl J Med 1996; 334: 1691-1696

4 Conte D, Fraquelli M, Prati D, Colucci A, Minola E. Prevalence and clinical course of chronic hepatitis $\mathrm{C}$ virus (HCV) infection and rate of HCV vertical transmission in a cohort of 15,250 pregnant women. Hepatology 2000; 31: 751-755

5 Haley RW, Fischer RP. Commercial tattooing as a potentially important source of hepatitis $\mathrm{C}$ infection. Clinical epidemiology of 626 consecutive patients unaware of their hepatitis C serologic status. Medicine (Baltimore) 2001; 80: 134-151

6 Akahane $Y$, Kojima M, Sugai Y, Sakamoto M, Miyazaki Y, Tanaka T, Tsuda F, Mishiro S, Okamoto H, Miyakawa Y, Mayumi M. Hepatitis $C$ virus infection in spouses of patients with type C chronic liver disease. Ann Intern Med 1994; 120: 748-752

7 Kenny-Walsh E. Clinical outcomes after hepatitis C infection from contaminated anti-D immune globulin. Irish Hepatology Research Group. N Engl J Med 1999; 340: 1228-1233
8 Di Bisceglie AM. Natural history of hepatitis C: its impact on clinical management. Hepatology 2000; 31: 1014-1018

9 Barrera JM, Bruguera M, Ercilla MG, Gil C, Celis R, Gil MP, del Valle Onorato M, Rodés J, Ordinas A. Persistent hepatitis $\mathrm{C}$ viremia after acute self-limiting posttransfusion hepatitis $\mathrm{C}$. Hepatology 1995; 21: 639-644

10 Alter MJ, Kruszon-Moran D, Nainan OV, McQuillan GM, Gao F, Moyer LA, Kaslow RA, Margolis HS. The prevalence of hepatitis C virus infection in the United States, 1988 through 1994. N Engl J Med 1999; 341: 556-562

11 Jaeckel E, Cornberg M, Wedemeyer H, Santantonio T, Mayer J, Zankel M, Pastore G, Dietrich M, Trautwein C, Manns MP. Treatment of acute hepatitis $\mathrm{C}$ with interferon alfa-2b. N Engl J Med 2001; 345: 1452-1457

12 Wiegand J, Buggisch P, Boecher W, Zeuzem S, Gelbmann CM, Berg T, Kauffmann W, Kallinowski B, Cornberg M, Jaeckel E, Wedemeyer H, Manns MP. Early monotherapy with pegylated interferon alpha-2b for acute hepatitis $C$ infection: the HEPNET acute-HCV-II study. Hepatology 2006; 43: 250-256

13 Gerlach JT, Diepolder HM, Zachoval R, Gruener NH, Jung MC, Ulsenheimer A, Schraut WW, Schirren CA, Waechtler M, Backmund M, Pape GR. Acute hepatitis C: high rate of both spontaneous and treatment-induced viral clearance. Gastroenterology 2003; 125: 80-88

14 National Institutes of Health Consensus Development Conference Statement: Management of hepatitis C: 2002-June 10-12, 2002. Hepatology 2002; 36: S3-S20

15 Manns MP, McHutchison JG, Gordon SC, Rustgi VK, Shiffman M, Reindollar R, Goodman ZD, Koury K, Ling M, Albrecht JK. Peginterferon alfa- $2 \mathrm{~b}$ plus ribavirin compared with interferon alfa- $2 b$ plus ribavirin for initial treatment of chronic hepatitis $C$ : a randomised trial. Lancet 2001; 358: 958-965

16 Fried MW, Shiffman ML, Reddy KR, Smith C, Marinos G, Gonçales FL, Häussinger D, Diago M, Carosi G, Dhumeaux D, Craxi A, Lin A, Hoffman J, Yu J. Peginterferon alfa-2a plus ribavirin for chronic hepatitis $\mathrm{C}$ virus infection. $N$ Engl J Med 2002; 347: 975-982

17 Strader DB, Wright T, Thomas DL, Seeff LB. Diagnosis, management, and treatment of hepatitis C. Hepatology 2004, 39: 1147-1171

18 Berg T, Kronenberger B, Hinrichsen H, Gerlach T, Buggisch P, Herrmann E, Spengler U, Goeser T, Nasser S, Wursthorn K, Pape GR, Hopf U, Zeuzem S. Triple therapy with amantadine in treatment-naive patients with chronic hepatitis C: a placebocontrolled trial. Hepatology 2003; 37: 1359-1367

19 Brillanti S, Levantesi F, Masi L, Foli M, Bolondi L. Triple antiviral therapy as a new option for patients with interferon nonresponsive chronic hepatitis C. Hepatology 2000; 32: 630-634

20 Teuber G, Pascu M, Berg T, Lafrenz M, Pausch J, Kullmann F, Ramadori G, Arnold R, Weidenbach H, Musch E, Junge U, Wiedmann KH, Herrmann E, Zankel M, Zeuzem S. Randomized, controlled trial with IFN-alpha combined with ribavirin with and without amantadine sulphate in nonresponders with chronic hepatitis C. J Hepatol 2003; 39: 606-613

21 De Francesco R, Migliaccio G. Challenges and successes in developing new therapies for hepatitis C. Nature 2005; 436 : 953-960

22 Pawlotsky JM, McHutchison JG. Hepatitis C. Development of new drugs and clinical trials: promises and pitfalls. Summary of an AASLD hepatitis single topic conference, Chicago, IL, February 27-March 1, 2003. Hepatology 2004; 39: 554-567

23 Gale M, Foy EM. Evasion of intracellular host defence by hepatitis C virus. Nature 2005; 436: 939-945

24 Arvin AM, Greenberg HB. New viral vaccines. Virology 2006; 344: 240-249

25 Houghton $\mathbf{M}$, Abrignani S. Prospects for a vaccine against the hepatitis $C$ virus. Nature 2005; 436: 961-966

26 McHutchison JG, Bartenschlager R, Patel K, Pawlotsky JM. The face of future hepatitis $C$ antiviral drug development: recent biological and virologic advances and their translation to drug development and clinical practice. J Hepatol 2006; 44: 411-421

27 Orland JR, Wright TL, Cooper S. Acute hepatitis C. Hepatology 2001; 33: 321-327 
28 Alter HJ, Seeff LB. Recovery, persistence, and sequelae in hepatitis $C$ virus infection: a perspective on long-term outcome. Semin Liver Dis 2000; 20: 17-35

29 Nomura H, Sou S, Tanimoto H, Nagahama T, Kimura Y, Hayashi J, Ishibashi H, Kashiwagi S. Short-term interferon-alfa therapy for acute hepatitis C: a randomized controlled trial. Hepatology 2004; 39: 1213-1219

30 Alberti A, Boccato S, Vario A, Benvegnù L. Therapy of acute hepatitis C. Hepatology 2002; 36: S195-S200

31 Hofer H, Watkins-Riedel T, Janata O, Penner E, Holzmann $\mathrm{H}$, Steindl-Munda P, Gangl A, Ferenci P. Spontaneous viral clearance in patients with acute hepatitis $\mathrm{C}$ can be predicted by repeated measurements of serum viral load. Hepatology 2003; 37: 60-64

32 Kaplan M, Gawrieh S, Cotler SJ, Jensen DM. Neutralizing antibodies in hepatitis $C$ virus infection: a review of immunological and clinical characteristics. Gastroenterology 2003; 125: 597-604

33 Fattovich G, Giustina G, Favarato S, Ruol A. A survey of adverse events in 11,241 patients with chronic viral hepatitis treated with alfa interferon. J Hepatol 1996; 24: 38-47

34 Peters MG, Terrault NA. Alcohol use and hepatitis C. Hepatology 2002; 36: S220-S225

35 Wedemeyer H, Jäckel E, Wiegand J, Cornberg M, Manns MP. Whom? When? How? Another piece of evidence for early treatment of acute hepatitis C. Hepatology 2004; 39: 1201-1203

36 Kamal SM, Ismail A, Graham CS, He Q, Rasenack JW, Peters T, Tawil AA, Fehr JJ, Khalifa Kel S, Madwar MM, Koziel MJ. Pegylated interferon alpha therapy in acute hepatitis C: relation to hepatitis $\mathrm{C}$ virus-specific $\mathrm{T}$ cell response kinetics. Hepatology 2004; 39: 1721-1731

37 Kamal SM, Fouly AE, Kamel RR, Hockenjos B, Al Tawil A, Khalifa KE, He Q, Koziel MJ, El Naggar KM, Rasenack J, Afdhal NH. Peginterferon alfa-2b therapy in acute hepatitis C: impact of onset of therapy on sustained virologic response. Gastroenterology 2006; 130: 632-638

38 Marcellin P, Boyer N, Gervais A, Martinot M, Pouteau M, Castelnau C, Kilani A, Areias J, Auperin A, Benhamou JP, Degott C, Erlinger S. Long-term histologic improvement and loss of detectable intrahepatic HCV RNA in patients with chronic hepatitis $C$ and sustained response to interferon-alpha therapy. Ann Intern Med 1997; 127: 875-881

39 McHutchison JG, Davis GL, Esteban-Mur R. Durability of sustained virologic response in patients with chronic hepatitis $\mathrm{C}$ after treatment with interferon- $2 \mathrm{~b}$ alone or in combination with ribavirin. Hepatology 2001; 34: 244A

40 Hadziyannis SJ, Sette H, Morgan TR, Balan V, Diago M, Marcellin P, Ramadori G, Bodenheimer H, Bernstein D, Rizzetto M, Zeuzem S, Pockros PJ, Lin A, Ackrill AM. Peginterferon-alpha2a and ribavirin combination therapy in chronic hepatitis $\mathrm{C}$ : a randomized study of treatment duration and ribavirin dose. Ann Intern Med 2004; 140: 346-355

41 Hoofnagle JH, Seeff LB. Peginterferon and ribavirin for chronic hepatitis C. N Engl J Med 2006; 355: 2444-2451

42 Lau JY, Tam RC, Liang TJ, Hong Z. Mechanism of action of ribavirin in the combination treatment of chronic HCV infection. Hepatology 2002; 35: 1002-1009

43 Di Bisceglie AM, Conjeevaram HS, Fried MW, Sallie R, Park Y, Yurdaydin C, Swain M, Kleiner DE, Mahaney K, Hoofnagle JH. Ribavirin as therapy for chronic hepatitis C. A randomized, double-blind, placebo-controlled trial. Ann Intern Med 1995; 123: 897-903

44 Bodenheimer HC, Lindsay KL, Davis GL, Lewis JH, Thung $\mathrm{SN}$, Seeff LB. Tolerance and efficacy of oral ribavirin treatment of chronic hepatitis C: a multicenter trial. Hepatology 1997; 26: 473-477

45 von Wagner M, Huber M, Berg T, Hinrichsen $H$, Rasenack J, Heintges T, Bergk A, Bernsmeier C, Häussinger D, Herrmann E, Zeuzem S. Peginterferon-alpha-2a (40KD) and ribavirin for 16 or 24 weeks in patients with genotype 2 or 3 chronic hepatitis $C$. Gastroenterology 2005; 129: 522-527

46 Mangia A, Santoro R, Minerva N, Ricci GL, Carretta V, Persico M, Vinelli F, Scotto G, Bacca D, Annese M, Romano M, Zechini
F, Sogari F, Spirito F, Andriulli A. Peginterferon alfa- $2 b$ and ribavirin for 12 vs. 24 weeks in HCV genotype 2 or 3. N Engl J Med 2005; 352: 2609-2617

47 Keating GM, Curran MP. Peginterferon-alpha-2a (40kD) plus ribavirin: a review of its use in the management of chronic hepatitis C. Drugs 2003; 63: 701-730

48 Scott LJ, Perry CM. Interferon-alpha-2b plus ribavirin: a review of its use in the management of chronic hepatitis $C$. Drugs 2002; 62: 507-556

49 Carithers RL, Emerson SS. Therapy of hepatitis C: metaanalysis of interferon alfa-2b trials. Hepatology 1997; 26: 83S-88S

50 Buti M, Sanchez-Avila F, Lurie Y, Stalgis C, Valdés A, Martell M, Esteban R. Viral kinetics in genotype 1 chronic hepatitis C patients during therapy with 2 different doses of peginterferon alfa-2b plus ribavirin. Hepatology 2002; 35: 930-936

51 Davis GL, Esteban-Mur R, Rustgi V, Hoefs J, Gordon SC, Trepo C, Shiffman ML, Zeuzem S, Craxi A, Ling MH, Albrecht $\mathrm{J}$. Interferon alfa- $2 \mathrm{~b}$ alone or in combination with ribavirin for the treatment of relapse of chronic hepatitis C. International Hepatitis Interventional Therapy Group. N Engl J Med 1998, 339: 1493-1499

52 Cammà $\mathrm{C}$, Bruno $\mathrm{S}$, Schepis $\mathrm{F}$, Lo Iacono $\mathrm{O}$, Andreone $\mathrm{P}$, Gramenzi AG, Mangia A, Andriulli A, Puoti M, Spadaro A, Freni M, Di Marco V, Cino L, Saracco G, Chiesa A, Crosignani A, Caporaso N, Morisco F, Rumi MG, Craxì A. Retreatment with interferon plus ribavirin of chronic hepatitis $C$ nonresponders to interferon monotherapy: a meta-analysis of individual patient data. Gut 2002; 51: 864-869

53 Cheng SJ, Bonis PA, Lau J, Pham NQ, Wong JB. Interferon and ribavirin for patients with chronic hepatitis $C$ who did not respond to previous interferon therapy: a meta-analysis of controlled and uncontrolled trials. Hepatology 2001; 33: 231-240

54 Shiffman ML. Management of interferon therapy nonresponders. Clin Liver Dis 2001; 5: 1025-1043

55 Zeuzem S, Herrmann E, Lee JH, Fricke J, Neumann AU, Modi M, Colucci G, Roth WK. Viral kinetics in patients with chronic hepatitis $C$ treated with standard or peginterferon alpha2a. Gastroenterology 2001; 120: 1438-1447

56 Zeuzem S, Lee JH, Franke A, Rüster B, Prümmer $\mathrm{O}$, Herrmann G, Roth WK. Quantification of the initial decline of serum hepatitis $\mathrm{C}$ virus RNA and response to interferon alfa. Hepatology 1998; 27: 1149-1156

57 Davis GL, Wong JB, McHutchison JG, Manns MP, Harvey $\mathrm{J}$, Albrecht J. Early virologic response to treatment with peginterferon alfa- $2 \mathrm{~b}$ plus ribavirin in patients with chronic hepatitis C. Hepatology 2003; 38: 645-652

58 Davis GL. Monitoring of viral levels during therapy of hepatitis C. Hepatology 2002; 36: S145-S151

59 Wong JB, Davis GL, McHutchinson JG. Clinical implications of testing viral response during ribavirin and peginterferon alfa-2b treatment for chronic hepatitis C. Hepatology 2002; 36: $281 \mathrm{~A}$

60 Zeuzem S, Buti M, Ferenci P, Sperl J, Horsmans Y, Cianciara J, Ibranyi E, Weiland O, Noviello S, Brass C, Albrecht J. Efficacy of 24 weeks treatment with peginterferon alfa- $2 \mathrm{~b}$ plus ribavirin in patients with chronic hepatitis $\mathrm{C}$ infected with genotype 1 and low pretreatment viremia. J Hepatol 2006; 44: 97-103

61 Shiffman ML, Pappas SC, Bacon B, Godofsky E, Nelson D, Harley H, Diago M, Lin A, Hooper G, Zeuzem S. Utility of virological response at weeks 4 and 12 in the prediction of SVR rates in genotype $2 / 3$ patients treated with PEGInterferon alfa2A (40KD) plus ribavirin: findings from accelerate. Hepatology 2006; 44: 97A340

62 Vogt M, Lang T, Frösner G, Klingler C, Sendl AF, Zeller A, Wiebecke B, Langer B, Meisner H, Hess J. Prevalence and clinical outcome of hepatitis $C$ infection in children who underwent cardiac surgery before the implementation of blood-donor screening. N Engl J Med 1999; 341: 866-870

63 Jacobson IM, Ahmed F, Russo MW, Brown RS, Lebovics E, Min A, Esposito S, Brau N, Tobias H, Klion F, Bini E, Brodsky N, Rovner D, Brass C NP-ISG. Pegylated interferon alfa-2b plus ribavirin in patients with chronic hepatitis $\mathrm{C}$. A trial in prior nonresponders to interferon monotherapy or combination 
therapy and in combination therpay relapsers: final results (abstr). Gastroenterology 2003; 124 Suppl 1: A714

64 Jonas MM. Children with hepatitis C. Hepatology 2002; 36: S173-S178

65 Wirth S, Lang T, Gehring S, Gerner P. Recombinant alfainterferon plus ribavirin therapy in children and adolescents with chronic hepatitis C. Hepatology 2002; 36: 1280-1284

66 Alberti A, Benvegnù L. Management of hepatitis C. J Hepatol 2003; 38 Suppl 1: S104-S118

67 Jacobson KR, Murray K, Zellos A, Schwarz KB. An analysis of published trials of interferon monotherapy in children with chronic hepatitis C. J Pediatr Gastroenterol Nutr 2002; 34: $52-58$

68 González-Peralta RP, Kelly DA, Haber B, Molleston J, Murray KF, Jonas MM, Shelton M, Mieli-Vergani G, Lurie Y, Martin S, Lang T, Baczkowski A, Geffner M, Gupta S, Laughlin $M$. Interferon alfa- $2 b$ in combination with ribavirin for the treatment of chronic hepatitis $C$ in children: efficacy, safety, and pharmacokinetics. Hepatology 2005; 42: 1010-1018

69 EASL International Consensus Conference on hepatitis C. Paris, 26-27 February 1999. Consensus statement. J Hepatol 1999; 31 Suppl 1: 3-8

70 Zeuzem S, Diago M, Gane E, Reddy KR, Pockros P, Prati D, Shiffman M, Farci P, Gitlin N, O'Brien CB, Lamour F, Lardelli P. Peginterferon alfa-2a (40 kilodaltons) and ribavirin in patients with chronic hepatitis $C$ and normal aminotransferase levels. Gastroenterology 2004; 127: 1724-1732

71 Edlin BR. Prevention and treatment of hepatitis C in injection drug users. Hepatology 2002; 36: S210-S219

72 Edlin BR, Seal KH, Lorvick J, Kral AH, Ciccarone DH, Moore LD, Lo B. Is it justifiable to withhold treatment for hepatitis C from illicit-drug users? N Engl J Med 2001; 345: 211-215

73 Heathcote J, Main J. Treatment of hepatitis C. J Viral Hepat 2005; 12: 223-235

74 Deyton LR, Walker RE, Kovacs JA, Herpin B, Parker M, Masur H, Fauci AS, Lane HC. Reversible cardiac dysfunction associated with interferon alfa therapy in AIDS patients with Kaposi's sarcoma. N Engl J Med 1989; 321: 1246-1249

75 Angulo MP, Navajas A, Galdeano JM, Astigarraga I, Fernández-Teijeiro A. Reversible cardiomyopathy secondary to alpha-interferon in an infant. Pediatr Cardiol 1999; 20: 293-294

76 Forns X, García-Retortillo M, Serrano T, Feliu A, Suarez F, de la Mata M, García-Valdecasas JC, Navasa M, Rimola A, Rodés J. Antiviral therapy of patients with decompensated cirrhosis to prevent recurrence of hepatitis $\mathrm{C}$ after liver transplantation. J Hepatol 2003; 39: 389-396

77 Gentil MA, Rocha JL, Rodríguez-Algarra G, Pereira P, López R, Bernal G, Muñoz J, Naranjo M, Mateos J. Impaired kidney transplant survival in patients with antibodies to hepatitis $\mathrm{C}$ virus. Nephrol Dial Transplant 1999; 14: 2455-2460

78 Strader DB. Understudied populations with hepatitis C. Hepatology 2002; 36: S226-S236

79 Russo MW, Goldsweig CD, Jacobson IM, Brown RS. Interferon monotherapy for dialysis patients with chronic hepatitis C: an analysis of the literature on efficacy and safety. Am J Gastroenterol 2003; 98: 1610-1615

80 Fabrizi F, Poordad FF, Martin P. Hepatitis C infection and the patient with end-stage renal disease. Hepatology 2002; 36: 3-10

81 Bruchfeld A, Lindahl K, Ståhle L, Söderberg M, Schvarcz R. Interferon and ribavirin treatment in patients with hepatitis C-associated renal disease and renal insufficiency. Nephrol Dial Transplant 2003; 18: 1573-1580

82 Gupta SK, Pittenger AL, Swan SK, Marbury TC, Tobillo E, Batra V, Sack M, Glue P, Jacobs S, Affrime M. Single-dose pharmacokinetics and safety of pegylated interferon-alpha2b in patients with chronic renal dysfunction. J Clin Pharmacol 2002; 42: 1109-1115

83 Dienstag JL, McHutchison JG. American Gastroenterological Association technical review on the management of hepatitis C. Gastroenterology 2006; 130: 231-264; quiz 214-217

84 Fried MW. Side effects of therapy of hepatitis $C$ and their management. Hepatology 2002; 36: S237-S244
85 Russo MW, Fried MW. Side effects of therapy for chronic hepatitis C. Gastroenterology 2003; 124: 1711-1719

86 Soza A, Everhart JE, Ghany MG, Doo E, Heller T, Promrat K, Park Y, Liang TJ, Hoofnagle JH. Neutropenia during combination therapy of interferon alfa and ribavirin for chronic hepatitis C. Hepatology 2002; 36: 1273-1279

87 McHutchison JG, Gordon SC, Schiff ER, Shiffman ML, Lee WM, Rustgi VK, Goodman ZD, Ling MH, Cort S, Albrecht $\mathrm{JK}$. Interferon alfa- $2 \mathrm{~b}$ alone or in combination with ribavirin as initial treatment for chronic hepatitis C. Hepatitis Interventional Therapy Group. N Engl J Med 1998; 339: 1485-1492

88 Zeuzem S, Feinman SV, Rasenack J, Heathcote EJ, Lai MY, Gane E, O'Grady J, Reichen J, Diago M, Lin A, Hoffman J, Brunda MJ. Peginterferon alfa-2a in patients with chronic hepatitis C. N Engl J Med 2000; 343: 1666-1672

89 Musselman DL, Lawson DH, Gumnick JF, Manatunga AK, Penna S, Goodkin RS, Greiner K, Nemeroff CB, Miller AH. Paroxetine for the prevention of depression induced by highdose interferon alfa. N Engl J Med 2001; 344: 961-966

90 Poynard T, McHutchison J, Manns M, Trepo C, Lindsay $\mathrm{K}$, Goodman Z, Ling MH, Albrecht J. Impact of pegylated interferon alfa- $2 \mathrm{~b}$ and ribavirin on liver fibrosis in patients with chronic hepatitis C. Gastroenterology 2002; 122: 1303-1313

91 Fontana RJ, Everson GT, Tuteja S, Vargas HE, Shiffman ML. Controversies in the management of hepatitis $C$ patients with advanced fibrosis and cirrhosis. Clin Gastroenterol Hepatol 2004 2: 183-197

92 Wright TL. Treatment of patients with hepatitis C and cirrhosis. Hepatology 2002; 36: S185-S194

93 Schalm SW, Weiland O, Hansen BE, Milella M, Lai MY Hollander A, Michielsen PP, Bellobuono A, Chemello L, Pastore G, Chen DS, Brouwer JT. Interferon-ribavirin for chronic hepatitis $C$ with and without cirrhosis: analysis of individual patient data of six controlled trials. Eurohep Study Group for Viral Hepatitis. Gastroenterology 1999; 117: 408-413

94 Heathcote EJ, Shiffman ML, Cooksley WG, Dusheiko GM, Lee SS, Balart L, Reindollar R, Reddy RK, Wright TL, Lin A, Hoffman J, De Pamphilis J. Peginterferon alfa-2a in patients with chronic hepatitis C and cirrhosis. N Engl J Med 2000; 343: 1673-1680

95 Everson GT. Long-term outcome of patients with chronic hepatitis $\mathrm{C}$ and decompensated liver disease treated with the LADR protocol. Hepatology 2002; 36: 297A

96 Everson GT. Treatment of patients with hepatitis $C$ virus on the waiting list. Liver Transpl 2003; 9: S90-S94

97 Everson GT, Trotter J, Forman L, Kugelmas M, Halprin A, Fey B, Ray C. Treatment of advanced hepatitis C with a low accelerating dosage regimen of antiviral therapy. Hepatology 2005; 42: 255-262

98 Crippin JS, McCashland T, Terrault N, Sheiner P, Charlton MR. A pilot study of the tolerability and efficacy of antiviral therapy in hepatitis $C$ virus-infected patients awaiting liver transplantation. Liver Transpl 2002; 8: 350-355

99 Poynard T, Ratziu V, McHutchison J, Manns M, Goodman Z, Zeuzem S, Younossi Z, Albrecht J. Effect of treatment with peginterferon or interferon alfa- $2 b$ and ribavirin on steatosis in patients infected with hepatitis C. Hepatology 2003; 38: 75-85

100 Bressler BL, Guindi M, Tomlinson G, Heathcote J. High body mass index is an independent risk factor for nonresponse to antiviral treatment in chronic hepatitis C. Hepatology 2003; 38: 639-644

101 Hickman IJ, Clouston AD, Macdonald GA, Purdie DM, Prins JB, Ash S, Jonsson JR, Powell EE. Effect of weight reduction on liver histology and biochemistry in patients with chronic hepatitis C. Gut 2002; 51: 89-94

102 Yoshida H, Shiratori Y, Moriyama M, Arakawa Y, Ide T, Sata M, Inoue O, Yano M, Tanaka M, Fujiyama S, Nishiguchi S, Kuroki T, Imazeki F, Yokosuka O, Kinoyama S, Yamada G, Omata M. Interferon therapy reduces the risk for hepatocellular carcinoma: national surveillance program of cirrhotic and noncirrhotic patients with chronic hepatitis $C$ in Japan. IHIT Study Group. Inhibition of Hepatocarcinogenesis 
by Interferon Therapy. Ann Intern Med 1999; 131: 174-181

103 Cammà C, Giunta M, Andreone $\mathrm{P}$, Craxì A. Interferon and prevention of hepatocellular carcinoma in viral cirrhosis: an evidence-based approach. J Hepatol 2001; 34: 593-602

104 Papatheodoridis GV, Papadimitropoulos VC, Hadziyannis SJ. Effect of interferon therapy on the development of hepatocellular carcinoma in patients with hepatitis $C$ virusrelated cirrhosis: a meta-analysis. Aliment Pharmacol Ther 2001; 15: 689-698

105 Seaberg EC, Belle SH, Beringer KC, Schivins JL, Detre KM. Liver transplantation in the United States from 1987-1998: updated results from the Pitt-UNOS Liver Transplant Registry. Clin Transpl, 1998:17-37.

106 Brown RS. Hepatitis C and liver transplantation. Nature 2005; 436: $973-978$

107 Forman LM, Lewis JD, Berlin JA, Feldman HI, Lucey MR. The association between hepatitis $\mathrm{C}$ infection and survival after orthotopic liver transplantation. Gastroenterology 2002; 122: 889-896

108 Féray C, Caccamo L, Alexander GJ, Ducot B, Gugenheim J, Casanovas T, Loinaz C, Gigou M, Burra P, Barkholt L, Esteban R, Bizollon T, Lerut J, Minello-Franza A, Bernard $\mathrm{PH}$, Nachbaur K, Botta-Fridlund D, Bismuth H, Schalm SW, Samuel D. European collaborative study on factors influencing outcome after liver transplantation for hepatitis C. European Concerted Action on Viral Hepatitis (EUROHEP) Group. Gastroenterology 1999; 117: 619-625

109 Neumann UP, Berg T, Bahra M, Seehofer D, Langrehr JM, Neuhaus R, Radke C, Neuhaus P. Fibrosis progression after liver transplantation in patients with recurrent hepatitis C. J Hepatol 2004; 41: 830-836

110 Charlton M. Hepatitis C infection in liver transplantation. Am J Transplant 2001; 1: 197-203

111 Berenguer M. Natural history of recurrent hepatitis C. Liver Transpl 2002; 8: S14-S18

112 Samonakis DN, Triantos CK, Thalheimer U, Quaglia A, Leandro G, Teixeira R, Papatheodoridis GV, Sabin CA, Rolando N, Davies S, Dhillon AP, Griffiths P, Emery V, Patch DW, Davidson BR, Rolles K, Burroughs AK. Immunosuppression and donor age with respect to severity of $\mathrm{HCV}$ recurrence after liver transplantation. Liver Transpl 2005; 11: 386-395

113 Berenguer M, Prieto M, San Juan F, Rayón JM, Martinez F, Carrasco D, Moya A, Orbis F, Mir J, Berenguer J. Contribution of donor age to the recent decrease in patient survival among HCV-infected liver transplant recipients. Hepatology 2002; 36: 202-210

114 Lake JR, Shorr JS, Steffen BJ, Chu AH, Gordon RD, Wiesner RH. Differential effects of donor age in liver transplant recipients infected with hepatitis $B$, hepatitis $C$ and without viral hepatitis. Am J Transplant 2005; 5: 549-557

115 Everson GT. Impact of immunosuppressive therapy on recurrence of hepatitis C. Liver Transpl 2002; 8: S19-S27

116 McTaggart RA, Terrault NA, Vardanian AJ, Bostrom A, Feng S. Hepatitis C etiology of liver disease is strongly associated with early acute rejection following liver transplantation. Liver Transpl 2004; 10: 975-985

117 Prieto M, Berenguer M, Rayón JM, Córdoba J, Argüello L, Carrasco D, García-Herola A, Olaso V, De Juan M, Gobernado M, Mir J, Berenguer J. High incidence of allograft cirrhosis in hepatitis $\mathrm{C}$ virus genotype $1 \mathrm{~b}$ infection following transplantation: relationship with rejection episodes. Hepatology 1999; 29: 250-256

118 Thomas RM, Brems JJ, Guzman-Hartman G, Yong S, Cavaliere P, Van Thiel DH. Infection with chronic hepatitis C virus and liver transplantation: a role for interferon therapy before transplantation. Liver Transpl 2003; 9: 905-915

119 Samuel D, Bizollon T, Feray C, Roche B, Ahmed SN, Lemonnier C, Cohard M, Reynes M, Chevallier M, Ducerf C, Baulieux J, Geffner M, Albrecht JK, Bismuth H, Trepo C. Interferon-alpha $2 \mathrm{~b}$ plus ribavirin in patients with chronic hepatitis $C$ after liver transplantation: a randomized study. Gastroenterology 2003; 124: 642-650
120 Lavezzo B, Franchello A, Smedile A, David E, Barbui A, Torrani M, Ottobrelli A, Zamboni F, Fadda M, Bobbio A, Salizzoni M, Rizzetto M. Treatment of recurrent hepatitis C in liver transplants: efficacy of a six versus a twelve month course of interferon alfa $2 \mathrm{~b}$ with ribavirin. J Hepatol 2002; 37: 247-252

121 Berenguer M, Prieto M, Palau A, Carrasco D, Rayón JM, Calvo F, Berenguer J. Recurrent hepatitis C genotype $1 \mathrm{~b}$ following liver transplantation: treatment with combination interferon-ribavirin therapy. Eur J Gastroenterol Hepatol 2004; 16: 1207-1212

122 Mukherjee S, Rogge J, Weaver L, Schafer DF. Pilot study of pegylated interferon alfa- $2 \mathrm{~b}$ and ribavirin for recurrent hepatitis C after liver transplantation. Transplant Proc 2003; 35: 3042-3044

123 Chalasani N, Manzarbeitia C, Ferenci P, Vogel W, Fontana RJ, Voigt M, Riely C, Martin P, Teperman L, Jiao J, LopezTalavera JC. Peginterferon alfa-2a for hepatitis C after liver transplantation: two randomized, controlled trials. Hepatology 2005; 41: 289-298

124 Bahr MJ, Manns MP. Changing faces-natural course and treatment of hepatitis $\mathrm{C}$ after liver transplantation. J Hepatol 2004; 40: 699-701

125 Dumortier J, Scoazec JY, Chevallier P, Boillot O. Treatment of recurrent hepatitis $C$ after liver transplantation: a pilot study of peginterferon alfa- $2 \mathrm{~b}$ and ribavirin combination. J Hepatol 2004; 40: 669-674

126 Garcia-Retortillo M, Forns X. Prevention and treatment of hepatitis $C$ virus recurrence after liver transplantation. J Hepatol 2004; 41: 2-10

127 Rodriguez-Luna $\mathbf{H}$, Khatib A, Sharma P, De Petris G, Williams JW, Ortiz J, Hansen K, Mulligan D, Moss A, Douglas DD, Balan V, Rakela J, Vargas HE. Treatment of recurrent hepatitis $\mathrm{C}$ infection after liver transplantation with combination of pegylated interferon alpha $2 \mathrm{~b}$ and ribavirin: an open-label series. Transplantation 2004; 77: 190-194

128 Shergill AK, Khalili M, Straley S, Bollinger K, Roberts JP, Ascher NA, Terrault NA. Applicability, tolerability and efficacy of preemptive antiviral therapy in hepatitis C-infected patients undergoing liver transplantation. Am J Transplant 2005; 5: 118-124

129 Gane EJ, Lo SK, Riordan SM, Portmann BC, Lau JY, Naoumov $\mathrm{NV}$, Williams R. A randomized study comparing ribavirin and interferon alfa monotherapy for hepatitis $\mathrm{C}$ recurrence after liver transplantation. Hepatology 1998; 27: 1403-1407

130 Sheiner PA. Hepatitis C after liver transplantation. Semin Liver Dis 2000; 20: 201-209

131 Gane E. Treatment of recurrent hepatitis C. Liver Transpl 2002; 8: S28-S37

132 Sherman KE, Rouster SD, Chung RT, Rajicic N. Hepatitis $C$ Virus prevalence among patients infected with Human Immunodeficiency Virus: a cross-sectional analysis of the US adult AIDS Clinical Trials Group. Clin Infect Dis 2002; 34: 831-837

133 Goedert JJ, Eyster ME, Lederman MM, Mandalaki T, De Moerloose P, White GC, Angiolillo AL, Luban NL, Sherman KE, Manco-Johnson M, Preiss L, Leissinger C, Kessler CM, Cohen AR, DiMichele D, Hilgartner MW, Aledort LM, Kroner BL, Rosenberg PS, Hatzakis A. End-stage liver disease in persons with hemophilia and transfusion-associated infections. Blood 2002; 100: 1584-1589

134 Benhamou Y, Di Martino V, Bochet M, Colombet G, Thibault V, Liou A, Katlama C, Poynard T. Factors affecting liver fibrosis in human immunodeficiency virus-and hepatitis $C$ virus-coinfected patients: impact of protease inhibitor therapy. Hepatology 2001; 34: 283-287

135 Thomas DL. Hepatitis C and human immunodeficiency virus infection. Hepatology 2002; 36: S201-S209

136 Pérez-Olmeda M, Núñez M, Romero M, González J, Castro A, Arribas JR, Pedreira J, Barreiro P, García-Samaniego J, MartínCarbonero L, Jiménez-Nácher I, Soriano V. Pegylated IFNalpha2b plus ribavirin as therapy for chronic hepatitis $C$ in HIV-infected patients. AIDS 2003; 17: 1023-1028 
137 Chung RT, Andersen J, Volberding P, Robbins GK, Liu T, Sherman KE, Peters MG, Koziel MJ, Bhan AK, Alston B, Colquhoun D, Nevin T, Harb G, van der Horst C. Peginterferon Alfa-2a plus ribavirin versus interferon alfa2a plus ribavirin for chronic hepatitis C in HIV-coinfected persons. N Engl J Med 2004; 351: 451-459

138 Torriani FJ, Rodriguez-Torres M, Rockstroh JK, Lissen E, Gonzalez-García J, Lazzarin A, Carosi G, Sasadeusz J, Katlama C, Montaner J, Sette H, Passe S, De Pamphilis J, Duff F, Schrenk UM, Dieterich DT. Peginterferon Alfa-2a plus ribavirin for chronic hepatitis $\mathrm{C}$ virus infection in HIV-infected patients. N Engl J Med 2004; 351: 438-450

139 Carrat F, Bani-Sadr F, Pol S, Rosenthal E, Lunel-Fabiani F, Benzekri A, Morand P, Goujard C, Pialoux G, Piroth L, Salmon-Céron D, Degott C, Cacoub P, Perronne C. Pegylated interferon alfa-2b vs standard interferon alfa- $2 b$, plus ribavirin, for chronic hepatitis $\mathrm{C}$ in HIV-infected patients: a randomized controlled trial. JAMA 2004; 292: 2839-2848

140 Bräu N, Rodriguez-Torres M, Prokupek D, Bonacini M, Giffen CA, Smith JJ, Frost KR, Kostman JR. Treatment of chronic hepatitis $\mathrm{C}$ in $\mathrm{HIV} / \mathrm{HCV}$-coinfection with interferon alpha$2 b+$ full-course vs. 16-week delayed ribavirin. Hepatology 2004; 39: 989-998

141 Lafeuillade A, Hittinger G, Chadapaud S. Increased mitochondrial toxicity with ribavirin in $\mathrm{HIV} / \mathrm{HCV}$ coinfection. Lancet 2001; 357: 280-281

142 Qurishi N, Kreuzberg C, Lüchters G, Effenberger W, Kupfer B, Sauerbruch T, Rockstroh JK, Spengler U. Effect of antiretroviral therapy on liver-related mortality in patients with HIV and hepatitis C virus coinfection. Lancet 2003; 362: 1708-1713

143 Kottilil S, Polis MA, Kovacs JA. HIV Infection, hepatitis C infection, and HAART: hard clinical choices. JAMA 2004; 292: 243-250

144 Chung RT, Evans SR, Yang Y, Theodore D, Valdez H, Clark $R$, Shikuma C, Nevin T, Sherman KE. Immune recovery is associated with persistent rise in hepatitis $C$ virus RNA, infrequent liver test flares, and is not impaired by hepatitis $\mathrm{C}$ virus in co-infected subjects. AIDS 2002; 16: 1915-1923

145 Mangia A, Leandro G, Helbling B, Renner EL, Tabone M, Sidoli L, Caronia S, Foster GR, Zeuzem S, Berg T, Di Marco V, Cino N, Andriulli A. Combination therapy with amantadine and interferon in naïve patients with chronic hepatitis C: meta-analysis of individual patient data from six clinical trials. J Hepatol 2004; 40: 478-483

146 Nelson D, Rustgi V, Balan V, McHutchinson JG, Davis GL, Lambiase L. A phase 2 study of albuferon in combination with ribavirin in nonresponders to prior interferon therapy for chronic hepatitis C. Hepatology 2005; 42: 278A

147 Wu JZ, Walker H, Lau JY, Hong Z. Activation and deactivation of a broad-spectrum antiviral drug by a single enzyme: adenosine deaminase catalyzes two consecutive deamination reactions. Antimicrob Agents Chemother 2003; 47: 426-431

148 Gish RG, Nelson D, Arora S, Fried MW, Reddy KR, Xu Y. Virologic response and safety outcomes in therapy-naive patients treated for chronic hepatitis $\mathrm{C}$ with viramidine in combination with pegylated interferon alfa-2a. J Hepatol 2005; 42: 39A

149 Lamarre D, Anderson PC, Bailey M, Beaulieu P, Bolger G, Bonneau P, Bös M, Cameron DR, Cartier M, Cordingley MG, Faucher AM, Goudreau N, Kawai SH, Kukolj G, Lagacé L, LaPlante SR, Narjes H, Poupart MA, Rancourt J, Sentjens RE, St George R, Simoneau B, Steinmann G, Thibeault D, Tsantrizos YS, Weldon SM, Yong CL, Llinàs-Brunet M. An NS3 protease inhibitor with antiviral effects in humans infected with hepatitis C virus. Nature 2003; 426: 186-189

150 Hinrichsen H, Benhamou Y, Wedemeyer H, Reiser M, Sentjens RE, Calleja JL, Forns X, Erhardt A, Crönlein J, Chaves RL, Yong CL, Nehmiz G, Steinmann GG. Short-term antiviral efficacy of BILN 2061, a hepatitis C virus serine protease inhibitor, in hepatitis $\mathrm{C}$ genotype 1 patients. Gastroenterology 2004; 127: 1347-1355

151 Reiser M, Hinrichsen H, Benhamou Y, Reesink HW, Wedemeyer H, Avendano C, Riba N, Yong CL, Nehmiz G, Steinmann GG. Antiviral efficacy of NS3-serine protease inhibitor BILN-2061 in patients with chronic genotype 2 and 3 hepatitis C. Hepatology 2005; 41: 832-835

152 Reesink HW, Zeuzem S, Weegink CJ, Forestier N, van Vliet A, van de Wetering de Rooij J. Final results of a phase 1B, multiple-dose study of VX-950, a hepatitis C virus protease inhibitor. Hepatology 2005; 42: 234A

153 Zeuzem S, Sarrazin C, Rouzier R, Tarral A, Brion N, Forestier N. Anti-viral activity of SCH 503034, a HCV protease inhibitor, administered as monotherapy in hepatitis $C$ genotype-1 (HCV-1) patients refractory to pegylated interferon (PEGINF-a). Hepatology 2005; 42: 233A

154 Kieffer T, Sarrazin C, Miller J, Traver S, Zhou Y, Bartels D, Hanzelka B, Müh U, Lin C, Reesink HW, Kwong A, Zeuzem S. Combination of Telaprevir (VX-950) and PEG-IFN-ALFA suppresses both wild-type virus and resistance variants in HCV genotype 1-infected patients in a 14-day phase $1 \mathrm{~B}$ study. Hepatology 2006; 44: 222A92

155 Afdahl N, Godofsky E, Dienstag JL, Rustgi V, Schick L, McEniry D. Final phase I / II trial results for NM283, a new polymerase inhibitor for hepatitis C: antiviral efficacy and tolerance in patients with $\mathrm{HCV}-1$ infection, including previous interferon failures. Hepatology 2004; 40: 726A

156 O'Brien C, Godofsky E, Rodriguez-Torres M, Afdahl N, Pappas SC, Pockros P. Randomized trial of valopicitabine (NM283), alone or with peg-interferon, vs. retreatment with peg-interferon plus ribavirin (pegINF/RBV) in hepatitis C patients with previous non-response to PegINF/RBV: first interim results. Hepatology 2005; 42: 234A

157 Lawitz E, Nguyen T, Younes Z, Santoro J, Gitlin N, McEniry D, Chasen R, Goff J. Knox S, Kleber K, Belanger B, Brown NA, Dieterich D, Valopicitabine (NM283) plus PEG-Interferon in treatment-naive hepatitis $\mathrm{C}$ patients with $\mathrm{HCV}$ genotype-1 infection: HCV RNA clearance during 24 weeks of treatment. Hepatology 2006; 44: 223A93

158 Ahlen G, Nystrom J, Pult I, Frelin L, Hultgren C, Sallberg $M$. In vivo clearance of hepatitis $C$ virus nonstructural 3/4A-expressing hepatocytes by DNA vaccine-primed cytotoxic T lymphocytes. J Infect Dis 2005; 192: 2112-2116

S- Editor Liu Y L- Editor Lutze M E- Editor Che YB 